\title{
Rh1 high activity binding peptides inhibit high percentages of Plasmodium falciparum FVO strain invasion
}

\author{
Gabriela Arévalo-Pinzón ${ }^{\mathrm{a}, \mathrm{b}}$, Hernando Curtidor ${ }^{\mathrm{a}, \mathrm{b}, *}$, Marina Muñoz ${ }^{\mathrm{a}, \mathrm{b}}$, Diana Suarez ${ }^{\mathrm{a}, \mathrm{b}}$, \\ Manuel A. Patarroyo ${ }^{\mathrm{a}, \mathrm{b}}$, Manuel E. Patarroyo ${ }^{\mathrm{a}, \mathrm{c}}$ \\ a Fundación Instituto de Inmunología de Colombia FIDIC, Carrera 50 \# 26-20, Bogotá, Colombia \\ b Universidad del Rosario, Calle 14 \# 6-25, Bogotá, Colombia \\ c Universidad Nacional de Colombia, Carrera 45 \# 26-85, Bogotá, Colombia
}

\section{A R T I C L E I N F O}

\section{Article history:}

Received 30 August 2012

Received in revised form 12 January 2013

Accepted 25 January 2013

Available online 8 February 2013

\section{Keywords:}

Malaria

Plasmodium falciparum

Reticulocyte binding-like

Synthetic peptide

\begin{abstract}
A B S T R A C T
Identifying the minimal functional regions of the proteins which the malaria parasite uses when invading its host cells constitutes the first and most important approach in an effective design for a chemically synthesised, multi-antigen, multi-stage, subunit-based vaccine. This work has been aimed at identifying the PfRh1 protein binding regions (residues 1-2580) belonging to the reticulocyte binding-like (RBL or $P$. falciparum $\mathrm{Rh}[\mathrm{PfRh}]$ ) family implicated in the parasite's alternative target cell invasion routes. Eighteen peptide regions (called high activity binding peptides - HABPs) binding to red blood cells (RBC) were identified in peptides mapped in a highly robust, specific and sensitive receptor-ligand assay. These HABPs were saturable in the experimental conditions assayed here and most had an alpha helix structure. Polymorphism studies revealed that only six of the eighteen HABPs identified had changes at amino acid level amongst the seven P. falciparum strains evaluated. Most HABPs' specific binding became altered when RBC were treated with neuraminidase, chymotrypsin and trypsin, suggesting differing sensitivity for RBC membrane receptors. After ascertaining that the Rh1 gene was transcribed and expressed in late-stage schizonts of the FCB-2 strain, invasion inhibition assays were carried out. When most of these HABPs were assayed in P. falciparum in vitro culture they were able to inhibit high percentages of FVO strain invasion compared to low inhibition percentages observed with the FCB-2 strain. This data shows small Rh1 regions' participation during invasion and suggests that these units should be included in further immunological and structural studies.
\end{abstract}

(C) 2013 Elsevier Ltd. All rights reserved.

\section{Introduction}

Plasmodium falciparum parasite's life-cycle is a complex process which is coordinated and regulated by a set of proteins stored in three specialised organelles called micronemes, rhoptries and dense granules [1]. It has been suggested that erythrocyte bindinglike (EBL) and reticulocyte binding-like (RBL or $P$. falciparum Rh [PfRh]) homologues could be responsible for interacting with host cells before tight junction (TJ) formation and facilitating entry through multiple alternative invasion routes [2-5]. Activating different invasion routes would be regulated by the availability of receptors on host cell membrane and differential expression of parasite proteins, called phenotypical variation [3,4]. Such mechanism is accompanied by marked functional redundancy between both

\footnotetext{
* Corresponding author at: Fundación Instituto de Inmunología de Colombia, Carrera 50 \# 26-20, Bogotá, Colombia. Tel.: +57 14815219 ; fax: +57 14815269.

E-mail addresses: hercur@gmail.com,

hernando.curtidor@urosario.edu.co (H. Curtidor).
}

groups of families which has shown that EBL protein functional loss could be compensated for by increased PfRh ligand expression [6]. Indeed, genetic disruption of the $e b a-175$ gene in some $P$. falciparum strains results from increased PfRh4 transcription and expression [4]. This mechanism could have evolved to facilitate $P$. falciparum evasion of invasion-inhibiting antibodies; there would thus be greater demand regarding a large number of ligands to ensure effective immunity [7].

The Rh family consists of PfRh1 (PFD0110w) [8], PfRh2a (PF13_0198) [9,10], PfRh2b (MAL13P1.176) [9,10], PfRh3 (appearing to be a pseudogene [11] but which is expressed during sporozoite stage) [12], PfRh4 (PFD1150c) [13] and PfRh5 (PFD1145c) [14]. These proteins are homologues for Plasmodium vivax reticulocyte-binding protein-1 and -2 (RBP-1 and RBP-2) [15] and the Plasmodium yoelii Py235 family [16]. Sub-cellular localisation studies have shown that all Rhs are expressed at the apical tip (in the rhoptries or micronemes) during the late intraerythrocyte stage which is in agreement with their role during invasion $[3,9,10,13]$. PfRh4 interacts with RBC by means of a sialic acid-independent route through specific binding to complement 

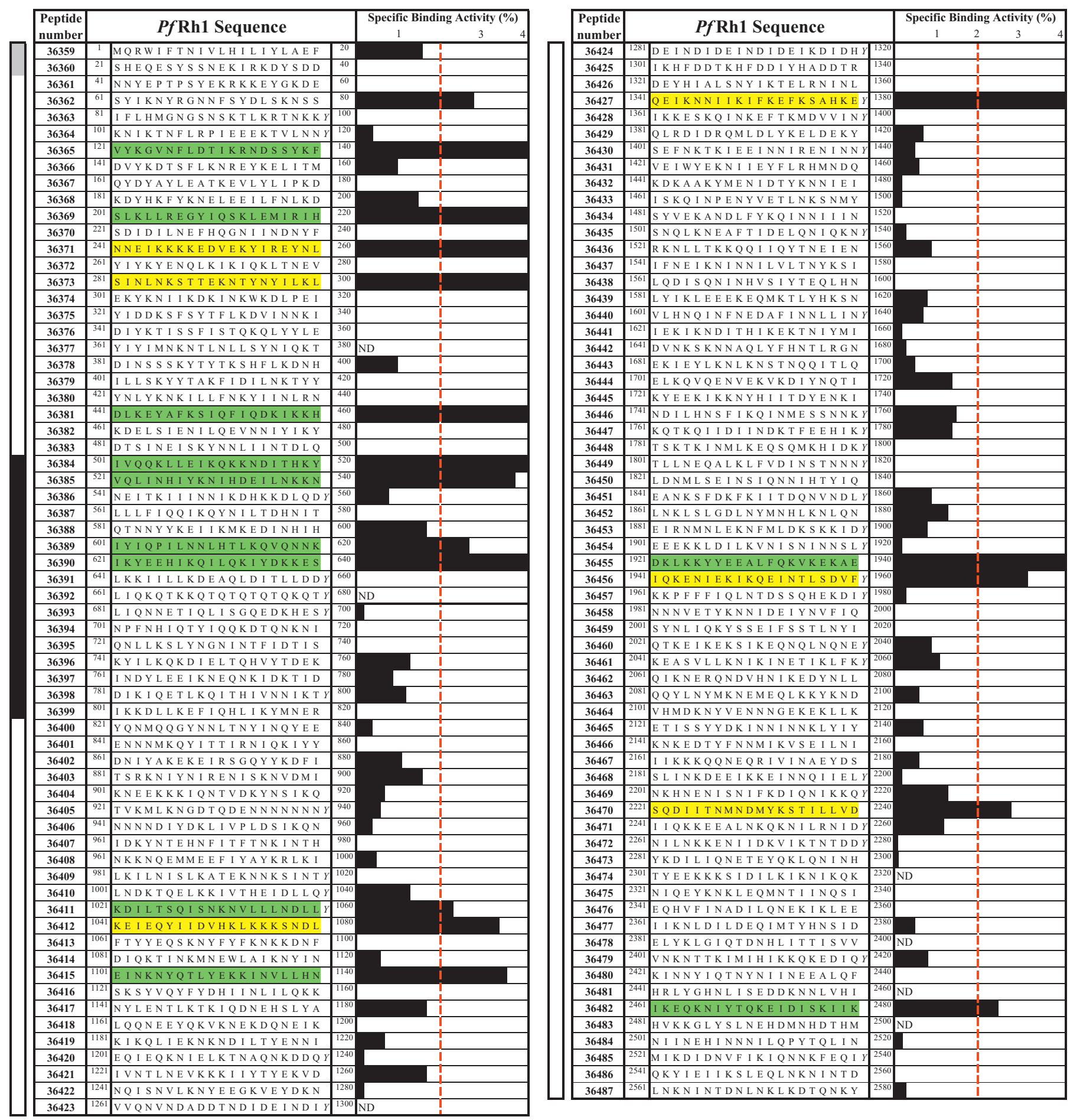

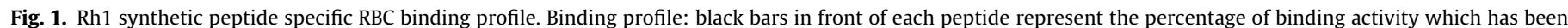

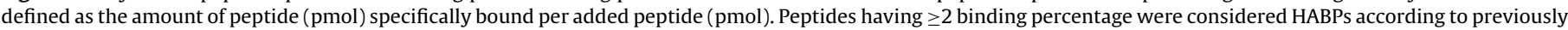

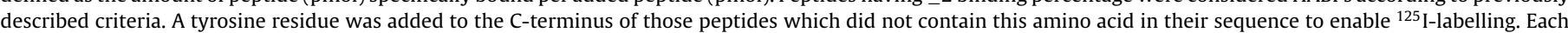

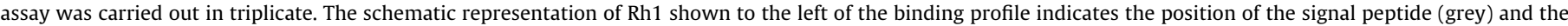
RII-3 RBC binding region previously identified by Gao et al. (black bar); ND, not determined.

1 receptor (CR1) [17]. Rh2a and Rh2b share a region comprising over $80 \%$ of the protein, only differing in the carboxy-terminal region $[9,10]$. Rh2b mediates invasion through a chymotrypsinsensitive, trypsin/neuraminidase-resistant receptor which has been called the $Z$ receptor and contains (together with PfRh2a) specific erythrocyte binding regions $[2,18,19]$. PfRh5 differs from other members of the Rh family regarding its small molecular size and being expressed in $P$. falciparum strains using different invasion routes, thereby providing a focus for new anti-malarial therapies. It has been found recently that PfRh5 has interacted with the erythrocyte membrane $[14,20]$, specifically with antigen from the Ok blood group called basigin [21]. It has also been suggested that Rh5 interacts with a novel cysteine-rich protein called the $P$. falciparum Rh5 interacting protein (PfRipr) which is located in the 

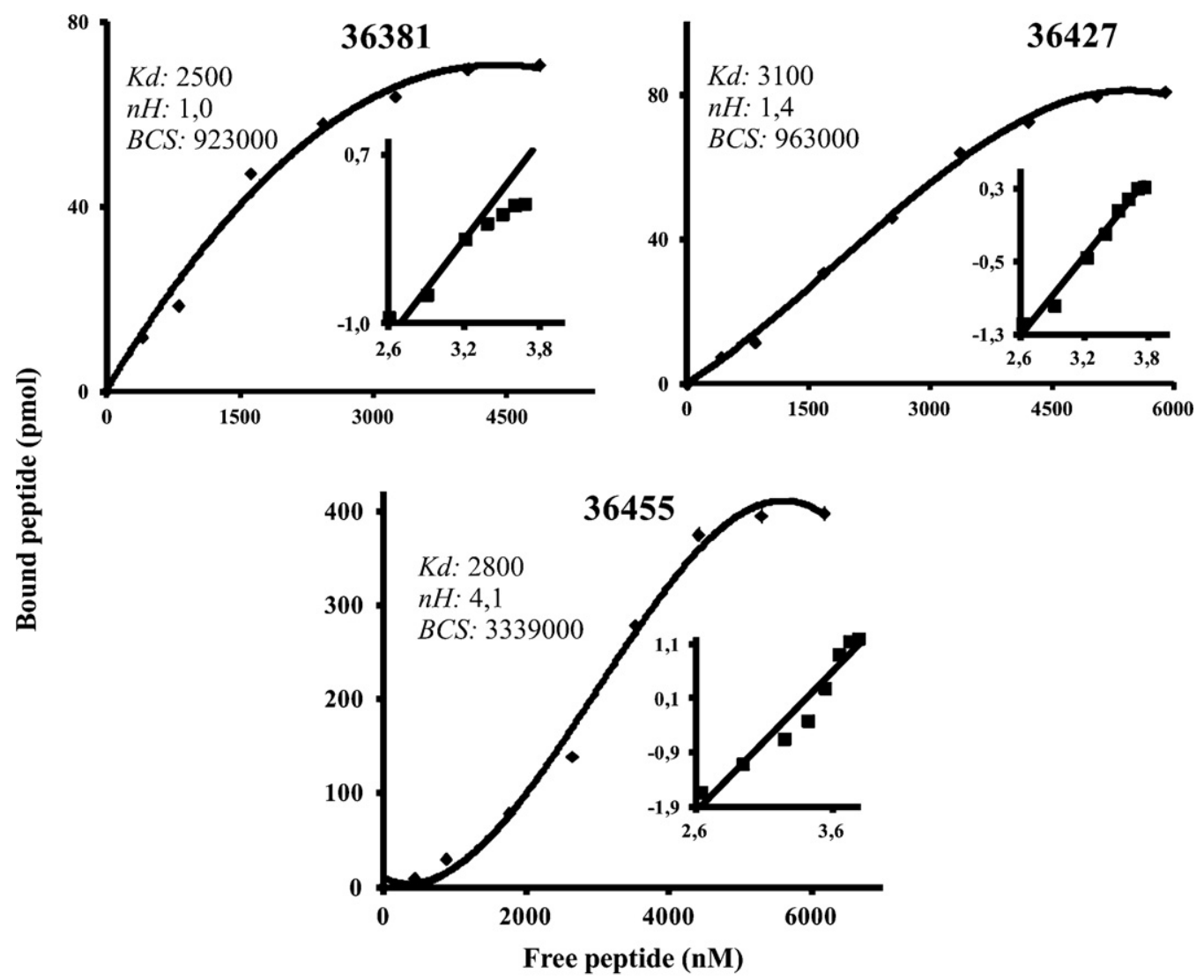

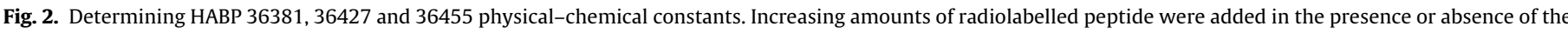

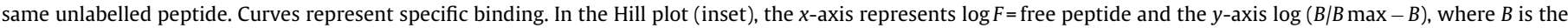
amount of bound peptide and $B$ max the maximum amount of bound peptide.

micronemes [22]. Antibodies directed against two regions of the PfRipr protein have shown different degrees of inhibition (37-80\%) depending on the invading strains, whether sialic acid-dependent or -independent [22].

This article focuses on one member of the PfRh family called $\mathrm{Rh} 1$, a high molecular weight protein having a signal peptide in its sequence towards the amino terminal and a transmembrane sequence in the carboxy-terminal. PfRh1 binds erythrocytes via a neuraminidase-sensitive and trypsin-, chymotrypsin-resistant protein called the $\mathrm{Y}$ receptor [23]. Analysis of Rh1 expression, together with that of other members of the family, has shown that sialic acid-dependent parasites lines, such as Dd2, MCamp and FCR3, express high levels of Rh1 and low levels of PfRh2a/2b. Alternatively, sialic acid-independent strains, such as 7G8 and HB3, express high PfRh2a/2b levels but low levels of Rh1 or a nonfunctional protein (i.e. 3D7), suggesting that proteins from this family are differentially expressed between parasite lines having different invasion phenotypes [8,23].

Unfortunately, the high diversity of RBL family sequences has hampered predicting functional regions within these proteins to date, contrary to that reported for the EBL family which contains a common erythrocyte binding region called domain binding ligand (DBL) [24]. Few Rh1 studies have been aimed at identifying the functionally important minimum binding regions involved in binding to erythrocytes $[25,26]$. Binding assays with Rh1 protein regions expressed in COS-7 cells have shown that only a long $\sim 334$ residuelong region (500-833), called RII-3, interacts with RBC in the same way as native PfRh1 protein [25]. Antibodies against the RII-3 region have been able to block invasion in T994, W2mef, FCR3 and Dd2 strain, confirming that parasites using a sialic acid-dependent invasion pathway are sensitive to the antibody targeting the PfRh1 binding domain [25]. Valbuena et al. [26] have reported that two synthetic peptides, $26332\left({ }^{101}\right.$ VFINDLDTYQYEYFYEWNQ $\left.{ }^{120}\right)$ and 26336 ( ${ }^{181}$ NTKETYLKELNKKKMLQNKK ${ }^{200}$ ), derived from the 7G8 strain, have high erythrocyte binding ability and were able to block invasion in vitro by up to $87 \%$.

Based on genomic and functional findings and the large number of key interactions during invasion involving Rh family member's active participation (particularly the Rh1 protein), fine mapping of this protein's minimum functional regions is important for further immunological evaluation as candidates for a broad spectrum vaccine, covering all the parasite's alternative invasion routes. Eighteen 20-residue-long sequences, called high activity binding peptides (HABPs), were identified, some of them presenting sub-micromolar dissociation constants and positive cooperativity. Such HABPs were able to inhibit FVO strain invasion, thereby highlighting these subunits' importance during invasion.

\section{Materials and methods}

This whole section can be found in Supplementary Material [27-36].

\section{Results}

\subsection{Rh1 peptides bound to RBC with high activity and affinity}

RBC binding assays were performed for determining Rh1 protein minimum binding sequences (covering residues M1 to K2572) specifically interacting with receptors on the RBC membrane. Eighteen peptides presenting specific binding, having slopes greater 
A

\begin{tabular}{|c|c|c|c|c|c|c|c|}
\hline \multirow[b]{2}{*}{ HABP } & \multirow[b]{2}{*}{ Sequence } & \multicolumn{6}{|c|}{ Parasite Line } \\
\hline & & $3 \mathrm{D} 7$ & $\begin{array}{l}\text { IGH- } \\
\text { CR14 }\end{array}$ & $\mathrm{Dd} 2$ & FCB2 & PAS2 & FVO \\
\hline 771 & NNEIKK & $\begin{array}{l}\text { aTG } \\
\text { Met }\end{array}$ & $\begin{array}{r}\text { gTG } \\
\text { Val }\end{array}$ & $\begin{array}{l}\text { gTG } \\
\text { Val }\end{array}$ & $\begin{array}{l}\text { aTG } \\
\text { Met }\end{array}$ & $\begin{array}{l}\text { aTG } \\
\text { Met }\end{array}$ & \\
\hline 36373 & SINLNKSTTEKNTYNNYILKL & $\begin{array}{c}\mathrm{aAC} \\
\text { Asn }\end{array}$ & $\begin{array}{c}\mathrm{aAC} \\
\text { Asn }\end{array}$ & $\begin{array}{l}\text { tAC } \\
\text { Tyr }\end{array}$ & $\begin{array}{l}\text { tAC } \\
\text { Tyr }\end{array}$ & $\begin{array}{l}\text { tAC } \\
\text { Tyr }\end{array}$ & $\begin{array}{l}\mathrm{tAC} \\
\mathbf{T y r}\end{array}$ \\
\hline 36412 & KEIEQYIIDV్HKLKKKSNDL & $\begin{array}{l}\text { CTa } \\
\text { Val }\end{array}$ & $\begin{array}{l}\text { CTa } \\
\text { Val }\end{array}$ & $\begin{array}{l}\mathrm{CTg} \\
\text { Val }\end{array}$ & $\begin{array}{l}\text { CTa } \\
\text { Val }\end{array}$ & $\begin{array}{l}\mathrm{CTa} \\
\text { Val }\end{array}$ & $\begin{array}{l}\text { CTa } \\
\text { Val }\end{array}$ \\
\hline te & QEIKN] & $\begin{array}{l}\text { aAA } \\
\text { Lys }\end{array}$ & $\begin{array}{c}\text { gAA } \\
\text { Glu }\end{array}$ & $\begin{array}{l}\text { gAA } \\
\text { Glu }\end{array}$ & $\begin{array}{c}\text { gAA } \\
\text { Glu }\end{array}$ & $\begin{array}{c}\text { gAA } \\
\text { Glu }\end{array}$ & $\begin{array}{c}\text { gAA } \\
\text { Glu }\end{array}$ \\
\hline 5456 & IQKENIEKIKQEINTLSD & $\begin{array}{c}\text { AtC } \\
\text { Ile }\end{array}$ & $\begin{array}{l}\mathrm{AaC} \\
\text { Asn }\end{array}$ & $\begin{array}{c}\text { AtC } \\
\text { Ile }\end{array}$ & $\begin{array}{c}\mathrm{AaC} \\
\text { Asn }\end{array}$ & $\begin{array}{c}\mathrm{AaC} \\
\text { Asn }\end{array}$ & $\begin{array}{l}\mathrm{AaC} \\
\text { Asn }\end{array}$ \\
\hline . & SQDIITNMNDMYKSTILU & $\begin{array}{l}\text { tAT } \\
\text { Tyr }\end{array}$ & $\begin{array}{l}\text { tAT } \\
\text { Tyr }\end{array}$ & $\begin{array}{c}\text { cAT } \\
\text { His }\end{array}$ & $\begin{array}{l}\text { cAT } \\
\text { His }\end{array}$ & $\begin{array}{c}\text { cAT } \\
\text { His }\end{array}$ & $\begin{array}{l}\text { cAT } \\
\text { His }\end{array}$ \\
\hline
\end{tabular}

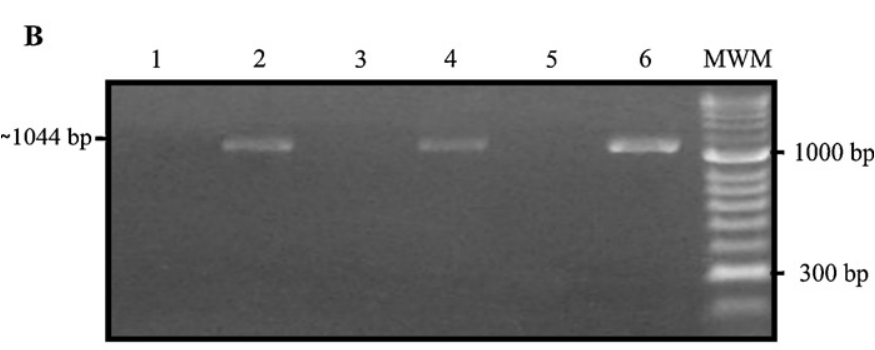

C

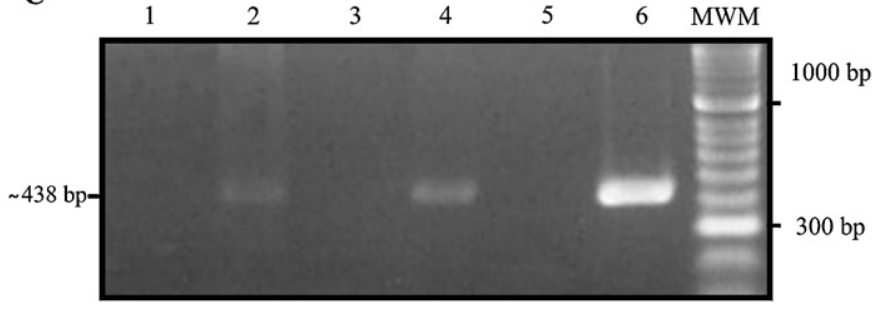

D

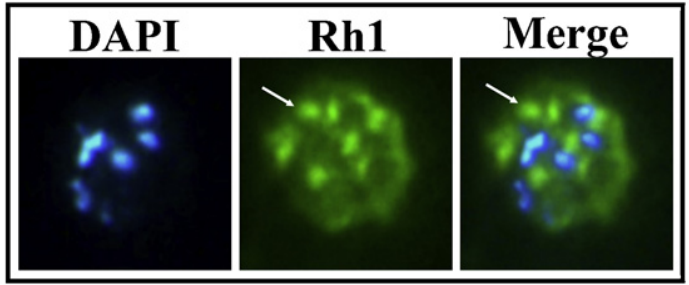

Fig. 3. Rh1 polymorphism, transcription and expression studies. A. Polymorphic amino acids in Rh1 HABPs. The HABP sequences shown were derived from 3D7 and compared to sequences from other $P$. falciparum strains. The amino acid underlined and shown in bold represents residues varying in the different strains. The figure shows the codon encoding each amino acid, the specific nucleotide which varied (in small letters) amongst strains and led to amino acid substitution regarding the reference strain. (B) rh1 PCR amplifications from cDNA: Lanes 1 and 2: PAS2 P. falciparum strain samples from asynchronous cultures. Lanes 3 and 4: FVO P. falciparum strain samples from asynchronous cultures. Lanes 5 and 6: FCB2 P. falciparum strain samples from schizonts. Lanes 1, 3 and 5 show PCR amplification from minus synthesis; lanes 2, 4 and 6 show PCR amplification from plus synthesis. (C) Pf25-IMP PCR amplification from cDNA. Same sample order as section B. (D) Late-stage schizonts from the FCB-2 strain were incubated with anti-Rh1 antibodies, revealed with FITClabelled anti-mouse IgG (green). Mature schizont nuclei were stained with DAPI (blue). Arrows indicate the typical dotted pattern observed in proteins localised in apical organelles.

than $2 \%$, were considered to be HABPs. HABPs were distributed throughout the whole protein, most of them between residues 61 and 1140 (Fig. 1).

It was found that HABP 36381, 36427 and $36455 \mathrm{Kd}$ was in the 2500-3100 sub-micromolar range and their $n H=>1$, indicating positive cooperativity. A variable number of BSC were found for HABPs 36381, 36427 and 36455 $(923,000-3,339,000)$ (Fig. 2), suggesting a saturable interaction with different receptors or with different sites on the same receptor.

\subsection{PfRh1 HABPs had conserved sequences}

The regions encoding each HABP in the FCB-2, PAS-2 and FVO strains were amplified by PCR for evaluating Rh1 protein polymorphism. The amplification sizes obtained from genomic DNA were $861,777,603,393,553,656$ and 415 base pairs (bp) for the respective combinations of primers used for the amplifications (Fig. S1). The control primers amplified a $438 \mathrm{bp}$ product corresponding to the IMP-Pf25 gene (Fig. S1).

Nucleotide and amino acid sequences for the three $P$. falciparum strains (FVO, FCB-2 and PAS-2) were aligned using Clustal W software [37] and compared to the sequences reported for the 3D7, IGH-CR14 and Dd2 strains (Fig. S2). The positions of strain-specific polymorphism in the regions where the HABPs were found were numbered according to the 3D7 reference strain.

HABPs 36362, 36365, 36369, 36381, 36384, 36385, 36389, 36390, 36411, 36415, 36455 and 36482 had 100\% amino acid identity amongst the P. falciparum strains studied (Supplementary Material). Polymorphism was found in HABPs 36371, 36373, 36412, 36427, 36456 and 36470 (Fig. 3A).

\subsection{Evaluating Rh1 transcription in P. falciparum FCB-2 strain schizonts}

Complementary DNA was synthesised from RNA in a synchronic parasite culture for evaluating Rh1 gene transcription in FCB-2 strain late-stage schizonts. A set of primers annealing as far as Rh1 protein transcript region 3' amplified a 1044 bp fragment having the expected molecular weight (Fig. 3B). The same fragment was amplified in PAS-2 and FVO strains from an asynchronic $P$. falciparum culture. No product was obtained when a cDNA synthesis reaction was carried out without adding reverse transcriptase, thereby ruling out any contamination of gDNA (Fig. 3C).

\subsection{Rh1 protein expression studies using the FCB-2 strain}

Prior studies have shown that depending on the $P$. falciparum strains, as well as the receptors available on the host cell, there was differential expression of Rh and EBL family members [3]. Based on these findings, Rh1 protein expression was examined in P. falciparum FCB-2 strain late-stage schizonts using polyclonal antibodies directed against several Rh1 protein regions. A punctate pattern (Fig. 3D), previously reported for apical organelles, was found which coincided with the fluorescence pattern reported for PfRh1 in the FVO strain [8].

\subsection{Binding assays with enzyme-treated RBC}

Binding assays were carried out with trypsin-, chymotrypsinand neuraminidase-treated RBC to evaluate the nature of HABP receptors and infer possible invasion routes (sialic acid-dependent or -independent route) in which minimum Rh1 units participate. The specific binding obtained with the different treatments was compared to $100 \%$ binding taken for untreated RBC. Table 1 shows that HABP 36365, 36369, 36381, 36427, 36455 and 36482 specific binding became abolished when RBC had been previously treated with neuraminidase; HABP 36390 and 36415 binding became reduced to $38 \%$ and $55 \%$. Treating RBC with chymotrypsin significantly reduced HABP 36381, 36415, 36427, 36455 and 36482 binding whilst HABP 36369 specific binding was maintained. RBC trypsin treatment abolished HABP 36369, 36381, 36390,36455 and 36482 specific binding and also reduced HABP 36415 binding to $10 \%$. HABP 36381, 36455 and 36482 specific 
Table 1

Rh1-derived HABP binding to enzyme-treated erythrocytes.

\begin{tabular}{|c|c|c|c|c|}
\hline \multirow[t]{2}{*}{ HABPS } & \multicolumn{4}{|c|}{ \% Specific binding } \\
\hline & Control & Neura & Chymo & Tryp \\
\hline 36365 & 100 & 0 & 38 & 124 \\
\hline 36369 & 100 & 0 & 99 & 0 \\
\hline 36381 & 100 & 0 & 1 & 7 \\
\hline 36390 & 100 & 38 & 39 & 0 \\
\hline 36412 & 100 & 92 & 23 & 0 \\
\hline 36415 & 100 & 55 & 0 & 10 \\
\hline 36427 & 100 & 0 & 0 & 84 \\
\hline 36455 & 100 & 5 & 5 & 0 \\
\hline 36482 & 100 & 0 & 4 & 0 \\
\hline
\end{tabular}

Standard deviations were below 5\%. Neura, neuraminidase; Chymo, chymotrypsin; Tryp, trypsin.

binding was the most affected by the three enzyme treatments (Table 1).

\subsection{Determining HABP secondary structure}

Circular dichroism studies were carried out for obtaining information about each HABP's secondary structure. All the peptides, except for HABPs 36362 and 36365, had ordered structures, an alpha-helical tendency predominating which was characterised by two minima at $209 \mathrm{~nm}$ and $222 \mathrm{~nm}$ and maximum molar ellipticity at $190 \mathrm{~nm}$ (Fig. 4). This data coincided with deconvolution data giving 70-90\% alpha-helical structures. Peptide 36362 had a disordered structure, having just 15\% structural elements (data not shown), whilst peptide 36365 contained around $40 \%$ alpha-helical elements (Fig. 4).

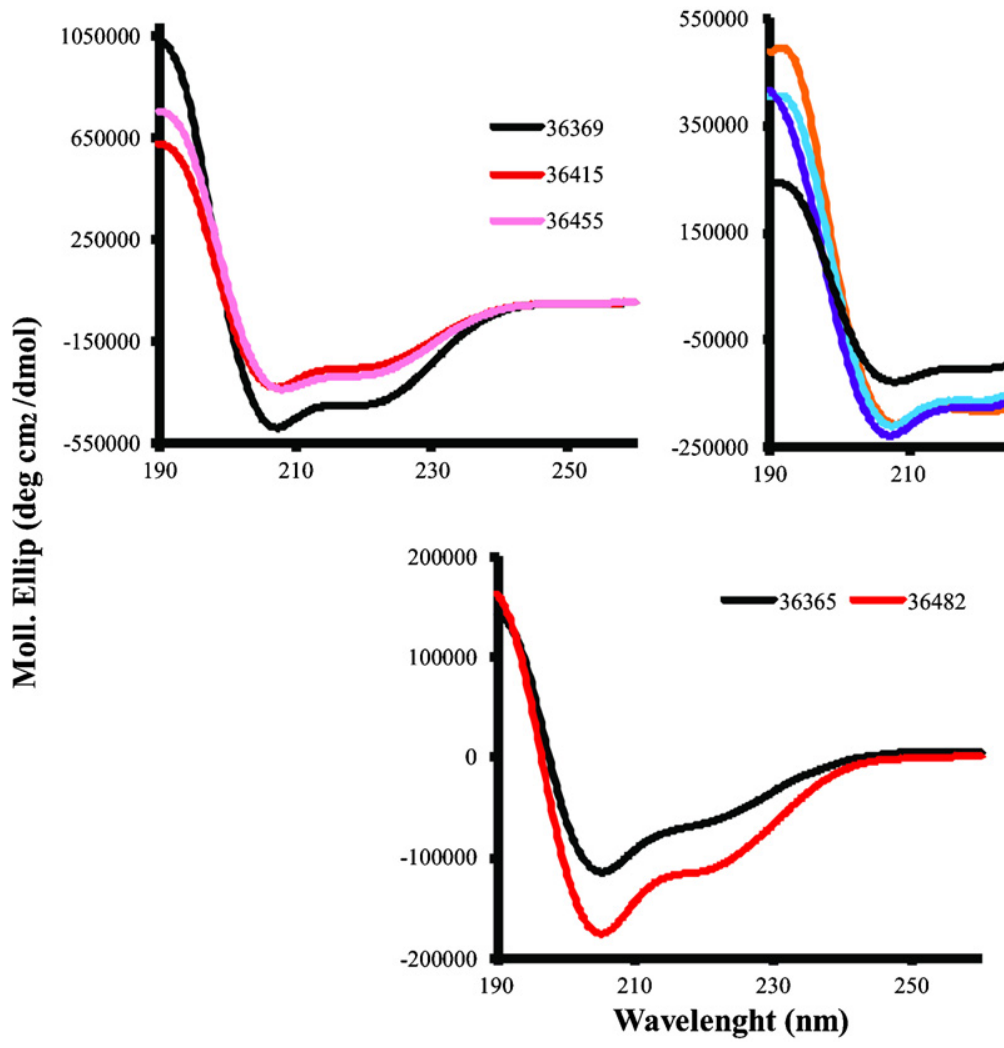

Table 2

Rh1 HABP inhibition of parasite invasion of RBCs.

\begin{tabular}{lll}
\hline Peptides & \multicolumn{2}{l}{ Invasion inhibition (\%) } \\
\cline { 2 - 3 } & $\begin{array}{l}\text { FVO } \\
(200 \mu \mathrm{M})\end{array}$ & FCB-2 \\
& & \\
\hline HABPs & $75 \pm 1$ & $7 \pm 1$ \\
36365 & $78 \pm 1$ & $\mathrm{ND}$ \\
36434 & $73 \pm 2$ & $2 \pm 1$ \\
36369 & $74 \pm 3$ & $9 \pm 1$ \\
36381 & $73 \pm 4$ & $3 \pm 3$ \\
36412 & $75 \pm 5$ & $\mathrm{ND}$ \\
36455 & $78 \pm 6$ & $8 \pm 1$ \\
36482 & $78 \pm 7$ & $4 \pm 3$ \\
36438 & & \\
LABP & $6 \pm 3$ & $5 \pm 2$ \\
36360 & & \\
Controls & $0 \pm 2$ & $0 \pm 3$ \\
Parasites & $91 \pm 1$ & $86 \pm 5$ \\
Chloroquine $(1.85 \mathrm{mg} / \mathrm{mL})$ & $94 \pm 1$ & $80 \pm 4$ \\
EGTA (1.9 mg/mL) & & \\
\hline
\end{tabular}

Mean \pm standard deviation of three experiments.

ND, not determined.

\subsection{Invasion inhibition assays}

Conserved HABPs were tested for their ability to inhibit invasion using FCB-2 or FVO strain to evaluate the role of PfRh1 during merozoite invasion. The resulting data showed that the HABPs inhibited high percentages (64-78\%) of FVO strain merozoite invasion of erythrocytes (Table 2 ) regarding that observed for the low activity binding peptide (LABP) (6\%). Interestingly, Rh1 HABPs inhibited low percentages $(<9 \%)$ of FCB-2 strain merozoite invasion of erythrocytes, similar to that found for LABP 36360 (data not shown). This data revealed two different invasion routes in which the FVO strain

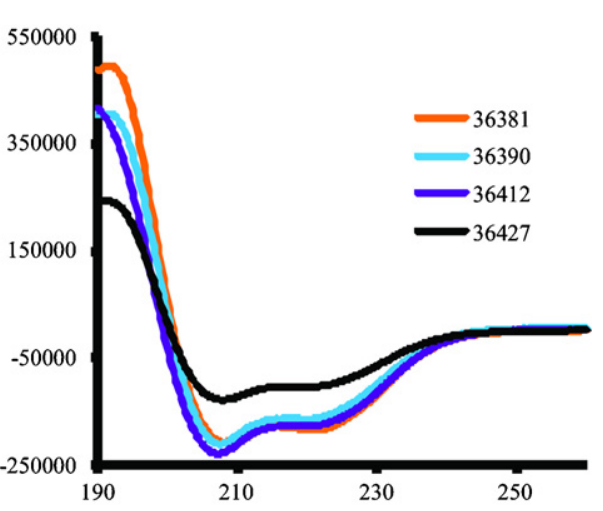

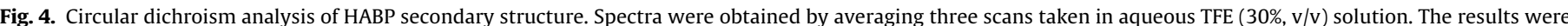

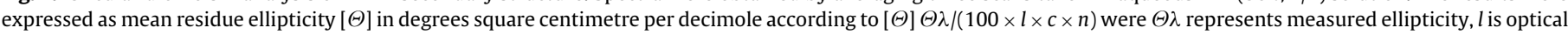
path length, $c$ peptide concentration and $n$ the number of amino acid residues in the sequence. 
required Rh1 for invasion whilst the FCB-2 strain, even though expressing Rh1 (Fig. 3D), was not used as antigen of preference for host cell invasion.

\section{Discussion}

It has been estimated that malaria caused by $P$. falciparum affects around 200 million people and causes a million deaths per year, most being children aged less than 5 years old $[38,39]$. Such figures constitute a grave public health problem for the world's tropical and subtropical regions suffering from this disease $[38,40]$. Even though several control mechanisms, such as the use of insecticide-impregnated mosquito-netting, implementing prevention and promotion campaigns and designing new drugs, have provided a partial solution to malaria, the appearance of new antigenic variants of the parasite as well as an increase in resistance to antimalarial drugs highlights the importance of developing a completely effective antimalarial vaccine.

In the search for such solution, large-scale research has been focused on identifying the proteins which the parasite uses to invade its host cells and their molecular and immunological characterisation [1]. Some of the antigens participating in the parasite's initial interactions with the host cell are thus known today, those participating in parasite reorientation, TJ formation, parasitophorous vacuole formation and host cell membrane remodelling $[41,42]$. The discovery of EBL and Rh family proteins has shown that $P$. falciparum can invade RBC of all ages $[43,44]$. These two families define a series of alternative invasion routes where differing receptor-ligand combinations ( $\sim 25$ routes) can be used independently and efficiently during invasion [3,45]. Variation in invasion phenotypes has been demonstrated with $P$. falciparum clinical isolates and laboratory-adapted clones [46]. It has also been demonstrated that a loss of function of some EBL member results in selection for increasing Rh family transcription [6]. It has also been suggested that EBL or Rh protein sequence polymorphism obliges the parasite to change the receptor so that the proteins can bind [47]. Such characteristics impose a great challenge for designing an antimalarial vaccine; this requires that the parasite ligands can be dissected within apt functional domains for inclusion in a multiantigen, multi-stage, chemically synthesised vaccine blocking the parasite's broad array of receptor-ligand interactions.

A specific and reliable methodology has helped us decipher intimate molecular interactions between peptides from most merozoite proteins and RBC membrane $[19,20]$. However, when these peptides or HABPs have been inoculated into Aotus monkeys they have been poorly antigenic, immunogenic and have not induced protection against a malarial challenge. Nevertheless, when residues involved in HABP-RBC interaction (critical binding residues) have been properly replaced by amino-acids having similar mass, volume and surface, but opposite polarity, such new modified peptides fit better into class II major histocompatibility complex (MHC II), allowing the suitable formation of the MHC II-peptide-T-cell receptor (TCR) complex and thereby improving the peptides' immunogenicity and protection-inducing ability [48]. Such immunological, structural and atomic analysis has supplied the necessary rules for designing a completely effective vaccine against malaria [48].

This study has identified the Rh1 protein's minimum functional subunits. Eighteen HABPs were found when the protein was fine mapped which were distributed throughout the Rh1 protein (Fig. 1), most being towards the protein's amino-terminal extreme and central part. Four of the HABPs identified $(36384,36385,36389$ and 36390) were localised in the RII-3 region (residues 500-833) (Fig. 1) which had been previously identified using expression in COS-7 cells and binding assays involving recombinant protein fragments [25]. HABPs 36381, 36427 and 36455 had saturable binding, $K d$ being in the sub-micromolar range suggesting high affinity interactions with receptors on RBC surface.

It is known that the extensive polymorphism in the parasite's proteins is one of the major obstacles in designing anti-malarial vaccines and drugs [49]. It has also been reported that polymorphism in some EBL proteins' binding regions alter their function and the specificity of the receptor to which they bind [47]. This data, added to phenotypical variation and functional redundancy between the EBL and Rh protein family means that polymorphism must be evaluated as selection criteria for vaccine candidates. Variation in HABPs 36371, 36373, 36412, 36427, 36456 and 36470 was found when Rh1 HABPs' polymorphism was evaluated, thereby excluding them from further immunological analysis (Fig. $3 \mathrm{~A}$ and Supplementary Material). The remaining HABPs did no present changes in their sequence when compared to six P. falciparum strains from distinct geographical areas.

It has been found that regardless of native HABPs' structural content they do not fit correctly into the MHC class II peptide binding groove, thereby drastically affecting the formation of a stable MHC-peptide-TCR complex [48]. Interestingly, structural changes were found regarding native HABPs when evaluating modified HABPs' structure [41,50]; for example, shortening HABPs' alpha helix resulted in modified peptides becoming associated with protection-inducing immunity [50]. Ascertaining native HABPs' secondary structure will thus lead to correlation with their modified peptides and an appropriate fit for inducing protection. All Rh1 HABPs evaluated by DC had high alpha-structure element content, coinciding with deconvolution data (Fig. 4).

The identity of most $P$. falciparum protein receptors has been characterised according to their sensitivity or resistance to enzymatic proteolysis with neuraminidase, trypsin and/or chymotrypsin. Such enzymatic treatment has helped to classify the two main invasion routes, i.e. sialic acid-independent and sialic aciddependent [51]. We used neuraminidase (which removes sialic acid residues from RBC receptors such as GPA), trypsin (which removes some proteins such as GPA and GPC) and chymotrypsin (which cleaves some band 3 protein loops). The binding of most HABPs evaluated was dramatically affected by neuraminidasetreated RBC (Table 1); these results agreed with previous studies thereby suggesting Rh1 participation in the sialic acid-dependent invasion route [23]. Enzymatically treating RBC with trypsin and chymotrypsin also affected some HABPs' specific binding, indicating an interaction with another type of receptor, thereby explaining the high number of BSC calculated during saturation studies (Fig. 2).

Rh1 transcription and expression were determined in FCB-2 strain late schizonts to try to understand the functional role of Rh1 HABPs (Fig. 3). Interestingly, only low inhibition percentages ( $\sim 6 \%)$ were observed when some conserved HABPs were tested in an invasion inhibition assay with the FCB-2 strain (Table 2), contrary to that found with the FVO strain where peptides were able to inhibit parasite invasion by up to $78 \%$ (Table 2 ). This data shows that the FVO strain preferentially uses the sialic acid-dependent invasion route compared to that found for the FCB-2 strain. Previous studies have reported that some $P$. falciparum strains cannot invade neuraminidase-treated RBCs efficiently and depend on sialic acidcontaining receptors for merozoite invasion (sialic acid-dependent route) whereas other strains can invade such enzyme-treated host cells (sialic acid-independent route) $[4,52,53]$. Even though the mechanism of invasion via these routes has not been completely understood, it has also been found that sialic acid-dependent strains over-express Rh1 and EBA-175 proteins [23,46] whilst Rh4 and EBA- 165 are over-expressed by sialic acid-independent strains [4]. Interestingly, Rh4 protein-derived HABPs inhibited invasion of the FCB-2 strain but this was not affected when RBCs had been pre-treated with neuraminidase, thereby suggesting that this strain 
invaded through a sialic acid-independent route [54]. Thus, even though Rh1 is expressed in the FCB2 strain (Fig. 3D), it is probably not used during invasion.

Previous studies have shown that many $P$. falciparum strains which are neuraminidase-sensitive or -resistant do express Rh1 (in different levels) $[23,25]$. Strains expressing normal or low Rh1 levels invade neuraminidase-treated RBC more efficiently than strains over-expressing the Rh1 protein $[23,25]$. Interestingly, it has been reported that differences in Rh1 expression levels dramatically modify antibodies' ability to inhibit invasion of different $P$. falciparum strains [25], thereby increasing the need to include more antigens for effectively blocking the parasite. In fact, antibodies directed against the Rh1 RII-3 region block high percentages of invasion by W2mef, FCR3 and Dd 2 strains (which over-express Rh1) by contrast with 3D7 and HB3 strains expressing low levels of Rh1 [25]. The fact that some level of Rh1 remains in neuraminidaseresistant strains has still not been fully elucidated. However, it has been suggested that both invasion mechanisms (i.e. sialic acidindependent and -dependent ones) may well work in tandem [25]. Our results also showed that using alternative routes correlated with evasion regarding blocking by our peptide subunits, highlighting the importance of using a range of HABPs from other proteins completely blocking invasion.

Mapping and identifying Rh1 minimum functional/binding regions is an essential step in ascertaining this protein's function. It has been shown here that these regions inhibited invasion by the FVO strain, requiring Rh1 for such invasion, whilst FCB-2 invaded by an alternative invasion route. This data suggested that minimal Rh1 binding regions are necessary for blocking the invasion of strains functionally expressing this protein as, together with other minimal functional subunits, they could block the parasite's broad invasion spectrum.

\section{Acknowledgment}

We would like to thank Jason Garry for translating this manuscript.

\section{Appendix A. Supplementary data}

Supplementary data associated with this article can be found, in the online version, at http://dx.doi.org/10.1016/j.vaccine. 2013.01.052.

\section{References}

[1] Cowman AF, Crabb BS. Invasion of red blood cells by malaria parasites. Cell 2006;124(February (4)):755-66.

[2] DeSimone TM, Jennings CV, Bei AK, Comeaux C, Coleman BI, Refour P, et al. Cooperativity between Plasmodium falciparum adhesive proteins for invasion into erythrocytes. Mol Microbiol 2009;72(May (3)):578-89.

[3] Duraisingh MT, Triglia T, Ralph SA, Rayner JC, Barnwell JW, McFadden GI, et al. Phenotypic variation of Plasmodium falciparum merozoite proteins directs receptor targeting for invasion of human erythrocytes. EMBO J 2003;22(March (5)):1047-57.

[4] Stubbs J, Simpson KM, Triglia T, Plouffe D, Tonkin CJ, Duraisingh MT, et al. Molecular mechanism for switching of $P$. falciparum invasion pathways into human erythrocytes. Science 2005;309(August (5739)):1384-7.

[5] Aikawa M, Miller LH, Johnson J, Rabbege J. Erythrocyte entry by malarial parasites. A moving junction between erythrocyte and parasite. J Cell Biol 1978;77(April (1)):72-82

[6] Lopaticki S, Maier AG, Thompson J, Wilson DW, Tham WH, Triglia T, et al. Reticulocyte and erythrocyte binding-like proteins function cooperatively in invasion of human erythrocytes by malaria parasites. Infect Immun 2011;79(March (3)):1107-17.

[7] Persson KE, McCallum FJ, Reiling L, Lister NA, Stubbs J, Cowman AF, et al. Variation in use of erythrocyte invasion pathways by Plasmodium falciparum mediates evasion of human inhibitory antibodies. J Clin Invest 2008;118(January (1)):342-51.

[8] Rayner JC, Vargas-Serrato E, Huber CS, Galinski MR, Barnwell JW. A Plasmodium falciparum homologue of Plasmodium vivax reticulocyte binding protein
(PvRBP1) defines a trypsin-resistant erythrocyte invasion pathway. J Exp Med 2001;194(December (11)):1571-81.

[9] Rayner JC, Galinski MR, Ingravallo P, Barnwell JW. Two Plasmodium falciparum genes express merozoite proteins that are related to Plasmodium vivax and Plasmodium yoelii adhesive proteins involved in host cell selection and invasion. Proc Natl Acad Sci U S A 2000;97(August (17)):9648-53.

[10] Triglia T, Thompson J, Caruana SR, Delorenzi M, Speed T, Cowman AF. Identification of proteins from Plasmodium falciparum that are homologous to reticulocyte binding proteins in Plasmodium vivax. Infect Immun 2001;69(February (2)):1084-92.

[11] Taylor HM, Triglia T, Thompson J, Sajid M, Fowler R, Wickham ME, et al. Plasmodium falciparum homologue of the genes for Plasmodium vivax and Plasmodium yoelii adhesive proteins, which is transcribed but not translated. Infect Immun 2001;69(June (6)):3635-45.

[12] Florens L, Washburn MP, Raine JD, Anthony RM, Grainger M, Haynes JD, et al. A proteomic view of the Plasmodium falciparum life cycle. Nature 2002;419(October (6906)):520-6.

[13] Kaneko O, Mu J, Tsuboi T, Su X, Torii M. Gene structure and expression of a Plasmodium falciparum 220-kDa protein homologous to the Plasmodium vivax reticulocyte binding proteins. Mol Biochem Parasitol 2002;121(May (2)):275-8.

[14] Rodriguez M, Lustigman S, Montero E, Oksov Y, Lobo CA. PfRH5: a novel reticulocyte-binding family homolog of Plasmodium falciparum that binds to the erythrocyte, and an investigation of its receptor. PLoS One 2008;3(10):e3300.

[15] Galinski MR, Xu M, Barnwell JW. Plasmodium vivax reticulocyte binding protein-2 (PvRBP-2) shares structural features with PvRBP-1 and the Plasmodium yoelii $235 \mathrm{kDa}$ rhoptry protein family. Mol Biochem Parasitol 2000;108(May (2)):257-62.

[16] Preiser PR, Jarra W, Capiod T, Snounou G. A rhoptry-protein-associated mechanism of clonal phenotypic variation in rodent malaria. Nature 1999;398(Apri (6728)):618-22.

[17] Tham WH, Wilson DW, Lopaticki S, Schmidt CQ, Tetteh-Quarcoo PB, Barlow PN et al. Complement receptor 1 is the host erythrocyte receptor for Plasmodium falciparum PfRh4 invasion ligand. Proc Natl Acad Sci U S A 2010;107(October (40)):17327-32

[18] Sahar T, Reddy KS, Bharadwaj M, Pandey AK, Singh S, Chitnis CE, et al. Plasmodium falciparum reticulocyte binding-like homologue protein 2 ( $\mathrm{PfRH} 2)$ is a key adhesive molecule involved in erythrocyte invasion. PLoS One 2011;6(2):e17102.

[19] Ocampo M, Vera R, Rodriguez LE, Curtidor H, Suarez J, Garcia J, et al. Identification of Plasmodium falciparum reticulocyte binding protein RBP-2 homologue $\mathrm{a}$ and $\mathrm{b}$ (PfRBP-2-Ha and - $\mathrm{Hb}$ ) sequences that specifically bind to erythrocytes. Parasitol Int 2004;53(March (1)):77-88.

[20] Arevalo-Pinzon G, Curtidor H, Munoz M, Patarroyo MA, Bermudez A, Patarroyo ME. A single amino acid change in the Plasmodium falciparum RH5 (PfRH5) human RBC binding sequence modifies its structure and determines speciesspecific binding activity. Vaccine 2012;30(January (3)):637-46.

[21] Crosnier C, Bustamante LY, Bartholdson SJ, Bei AK, Theron M, Uchikawa M, et al. Basigin is a receptor essential for erythrocyte invasion by Plasmodium falciparum. Nature 2011;480(December (7378)):534-7.

[22] Chen L, Lopaticki S, Riglar DT, Dekiwadia C, Uboldi AD, Tham WH, et al. An EGF-like protein forms a complex with PfRh5 and is required for invasion of human erythrocytes by Plasmodium falciparum. PLoS Pathog 2011;7(September (9)):e1002199.

[23] Triglia T, Duraisingh MT, Good RT, Cowman AF. Reticulocyte-binding protein homologue 1 is required for sialic acid-dependent invasion into human erythrocytes by Plasmodium falciparum. Mol Microbiol 2005;55(January (1)): 162-74.

[24] Chitnis CE, Miller LH. Identification of the erythrocyte binding domains of Plasmodium vivax and Plasmodium knowlesi proteins involved in erythrocyte invasion. J Exp Med 1994;180(August (2)):497-506.

[25] Gao X, Yeo KP, Aw SS, Kuss C, Iyer JK, Genesan S, et al. Antibodies targeting the PfRH1 binding domain inhibit invasion of Plasmodium falciparum merozoites. PLoS Pathog 2008;4(July (7)):e1000104.

[26] Valbuena JJ, Vera R, Garcia J, Puentes A, Curtidor H, Ocampo M, et al. Plasmodium falciparum normocyte binding protein (PfNBP-1) peptides bind specifically to human erythrocytes. Peptides 2003;24(July (7)):1007-14.

[27] Houghten RA. General method for the rapid solid-phase synthesis of large numbers of peptides: specificity of antigen-antibody interaction at the leve of individual amino acids. Proc Natl Acad Sci U S A 1985;82(August (15)): 5131-5.

[28] Tam JP, Heath WF, Merrifield RB. SN 1 and SN 2 mechanisms for the deprotection of synthetic peptides by hydrogen fluoride. Studies to minimize the tyrosine alkylation side reaction. Int J Pept Protein Res 1983;21(January (1)):57-65.

[29] Merrifield RB. Solid phase peptide synthesis. I. The synthesis of a tetrapeptide. J Am Chem Soc 1963;85:2149-54.

[30] Rodriguez LE, Curtidor H, Urquiza M, Cifuentes G, Reyes C, Patarroyo ME. Intimate molecular interactions of $P$. falciparum merozoite proteins involved in invasion of red blood cells and their implications for vaccine design. Chem Rev 2008;108(September (9)):3656-705.

[31] Trager W, Jensen JB. Human malaria parasites in continuous culture. Science 1976;193(August (4254)):673-5.

[32] Curtidor H, Arevalo G, Vanegas M, Vizcaino C, Patarroyo MA, Forero M, et al. Characterization of Plasmodium falciparum integral membrane protein 
Pf25-IMP and identification of its red blood cell binding sequences inhibiting merozoite invasion in vitro. Protein Sci 2008;17(September (9)):1494-504.

[33] Roccatano D, Colombo G, Fioroni M, Mark AE. Mechanism by which 2,2,2-trifluoroethanol/water mixtures stabilize secondary-structure formation in peptides: a molecular dynamics study. Proc Natl Acad Sci U S A 2002;99(September (19)):12179-84.

[34] Compton LA, Johnson Jr WC. Analysis of protein circular dichroism spectra for secondary structure using a simple matrix multiplication. Anal Biochem 1986;155(May (1)):155-67.

[35] Sreerama N, Venyaminov SY, Woody RW. Estimation of the number of alpha-helical and beta-strand segments in proteins using circular dichroism spectroscopy. Protein Sci 1999;8(February (2)):370-80.

[36] Larsen JE, Lund O, Nielsen M. Improved method for predicting linear B-cell epitopes. Immunome Res 2006;2:2.

[37] Combet C, Blanchet C, Geourjon C, Deleage G. NPS@: network protein sequence analysis. Trends Biochem Sci 2000;25(March (3)):147-50.

[38] World Health Organization. World Malaria Report 2011; 2011.

[39] Murray CJ, Rosenfeld LC, Lim SS, Andrews KG, Foreman KJ, Haring D, et al Global malaria mortality between 1980 and 2010: a systematic analysis. Lancet 2012;379(February (9814)):413-31.

[40] Greenwood BM, Fidock DA, Kyle DE, Kappe SH, Alonso PL, Collins FH, et al. Malaria: progress, perils, and prospects for eradication. J Clin Invest 2008;118(April (4)):1266-76.

[41] Patarroyo ME, Patarroyo MA. Emerging rules for subunit-based, multiantigenic, multistage chemically synthesized vaccines. Acc Chem Res 2008;41(3):377-86.

[42] Harvey KL, Gilson PR, Crabb BS. A model for the progression of receptor-ligand interactions during erythrocyte invasion by Plasmodium falciparum. Int J Parasitol 2012;42(May (6)):567-73.

[43] Galinski MR, Medina CC, Ingravallo P, Barnwell JW. A reticulocyte-binding protein complex of Plasmodium vivax merozoites. Cell 1992;69(June (7)):1213-26.

[44] Adams JH, Sim BK, Dolan SA, Fang X, Kaslow DC, Miller LH. A family of erythrocyte binding proteins of malaria parasites. Proc Natl Acad Sci U S A 1992;89(August (15)):7085-9.
[45] Iyer J, Gruner AC, Renia L, Snounou G, Preiser PR. Invasion of host cells by malaria parasites: a tale of two protein families. Mol Microbiol 2007;65(July (2)):231-49.

[46] Nery S, Deans AM, Mosobo M, Marsh K, Rowe JA, Conway DJ. Expression of Plasmodium falciparum genes involved in erythrocyte invasion varies among isolates cultured directly from patients. Mol Biochem Parasitol 2006;149(October (2)):208-15.

[47] Mayer DC, Mu JB, Kaneko O, Duan J, Su XZ, Miller LH. Polymorphism in the Plasmodium falciparum erythrocyte-binding ligand JESEBL/EBA-181 alters its receptor specificity. Proc Natl Acad Sci U S A 2004;101(February (8)): 2518-23.

[48] Patarroyo ME, Bermudez A, Patarroyo MA. Structural and immunological principles leading to chemically synthesized, multiantigenic, multistage, minimal subunit-based vaccine development. Chem Rev 2011;111(May (5)): 3459-507.

[49] McCutchan TF, de la Cruz VF, Good MF, Wellems TE. Antigenic diversity in Plasmodium falciparum. Prog Allergy 1988;41:173-92.

[50] Cifuentes G, Patarroyo ME, Urquiza M, Ramirez LE, Reyes C, Rodriguez R. Distorting malaria peptide backbone structure to enable fitting into MHC class II molecules renders modified peptides immunogenic and protective. J Med Chem 2003;46(May (11)):2250-3.

[51] Tham WH, Healer J, Cowman AF. Erythrocyte and reticulocyte binding-like proteins of Plasmodium falciparum. Trends Parasitol 2012;28(January (1)):23-30.

[52] Dolan SA, Miller LH, Wellems TE. Evidence for a switching mechanism in the invasion of erythrocytes by Plasmodium falciparum. J Clin Invest 1990;86(August (2)):618-24.

[53] Pasvol G. Receptors on red cells for Plasmodium falciparum and their interaction with merozoites. Philos Trans R Soc Lond B: Biol Sci 1984;307(November (1131)):189-200

[54] Garcia J, Curtidor H, Pinzon CG, Patarroyo MA, Vanegas M, Forero M, et al. Well-defined regions of the Plasmodium falciparum reticulocyte binding protein homologue 4 mediate interaction with red blood cell membrane. J Med Chem 2010;53(January (2)):811-21. 